\title{
Mechanic and Ennergy
}

http://dx.doi.org/10.1590/0370-44672016700195

Rafael Lemes Rodriguez

Graduando em Engenharia Mecânica

Universidade Estadual Paulista Júlio De Mesquita Filho

Departamento de Engenharia Mecânica

Bauru - São Paulo - Brasil

rodriguez.raaf@gmail.com

\section{Rodolfo Alexandre Hildebrandt}

Professor

Faculdade de Tecnologia SENAI Londrina

Departamento de Educação

Londrina - Paraná - Brasil

hildebrandt@hotmail.com.br

\section{José Claudio Lopes}

Mestrando em Engenharia Mecânica

Universidade Estadual Paulista Júlio De Mesquita Filho

Departamento de Engenharia Mecânica

São Paulo - São Paulo - Brasil

jclaudio.lopes@hotmail.com

\section{Hamilton Jose de Mello}

\section{Doutor}

Universidade Estadual Paulista Júlio De Mesquita Filho Departamento de Engenharia Mecânica

Bauru - São Paulo - Brasil

hamilton@feb.unesp.br

Rosemar Batista da Silva

Professor Associado

Universidade Federal de Uberlândia - UFU

Faculdade de Engenharia - Departamento Mecânica

Departamento de Engenharia Mecânica

Uberlândia - Minas Gerais - Brasil

rosemar.silva@ufu.br

\section{Paulo Roberto de Aguiar \\ Professor Titular \\ Universidade Estadual Paulista Júlio de Mesquita Filho Faculdade de Engenharia \\ Departamento de Engenharia Elétrica \\ Bauru - São Paulo - Brasil \\ aguiarpr@feb.unesp.br}

\section{Eduardo Carlos Bianchi}

Professor Titular

Universidade Estadual Paulista Júlio De Mesquita Filho

Faculdade de Engenharia

Departamento de Engenharia Mecânica

Bauru - São Paulo - Brasil

bianchi@feb.unesp.br

\section{Application viability evaluation of the Minimum Quantity Lubrication coolant technique under different flow rates in Plunge Cylindrical Grinding of the ABNT 4340 steel with aluminum oxide wheel}

\begin{abstract}
The coolant delivery technique known as Minimal Quantity Lubrication (MQL) has been employed in machining since the end of the 20th Century and has gained considerable evidence in the last years as a viable alternative to the use of the conventional coolant technique (flood). Due to the low oil flow rate delivered by the MQL technique in grinding operations, that generally varies from 20 to $240 \mathrm{ml} / \mathrm{h}$ in relation to near $600,000 \mathrm{ml} / \mathrm{h}$ flow rate of the conventional coolant technique, the MQL technique provides a reduced risk for human health and environmental damage associated with the use, maintenance and disposal of cutting fluids. In this context, this study was carried out to evaluate the application viability of the minimum quantity lubrication coolant technique under different flow rates in the plunge cylindrical grinding of ABNT 4340 steel with an aluminum oxide wheel. Three flow rates were tested: 30, 60 and $120 \mathrm{ml} / \mathrm{h}$. Grinding trials with the conventional coolant delivery method were also tested for comparative purposes. The output variables used to assess the efficiency of the MQL technique in this work are: roughness, roundness and hardness of the workpiece. Grinding wheel wear and power consumption were also monitored. The results showed that, despite the higher values of roughness and roundness of the workpiece, as well as the grinding wheel wear, the values of these same parameters obtained after machining with the MQL technique were close to those obtained after machining with the conventional technique. No thermal damages and cracks on the machined surface, or even below the machined surface, were observed after grinding ABNT 4340 steel irrespective of the coolant-lubrication condition investigated. The results showed that the MQL with $120 \mathrm{ml} / \mathrm{h}$ can be an alternative coolant technique due to cleaner environment and lower consumption of fluid in grinding under the conditions investigated in this work.
\end{abstract}

keywords: cutting fluid, MQL technique, flow rate, cylindrical grinding, alumina oxide wheel, roughness, roundness, hardness, wheel wear. 


\section{Introduction}

A grinding operation is employed in the machining process in order to give the workpiece a combination between superior finishing (less than 1.6 $\mu \mathrm{m}$ ) and accuracy IT3-IT6 (Malkin and Guo, 2008). Nguyen and Butler (2005) describe the grinding operation as one of the finishing processes used in machining, whereby the grinding process involves low rate of material removal by an abrasive tool compared to the geometrically-defined cutting edge process.

There are some particular characteristics inherent to the grinding process, for example, the intense interaction between tool abrasives and workpiece; they can promote thermal damages by friction and plastic deformation. In general, the great amount of heat generated by the cutting action is directed to the workpiece due to the low thermal conductivity of conventional abrasives at high grinding temperatures and small sections of chips formed. If the quantity of heat is not adequately removed by a means such as cutting fluid, the workpiece will be subjected to thermal damages, where the most common are: cracks, grinding burns, microstructure alterations and residual tensile stress (Marinescu et al, 2013). The great amount of energy and high temperatures which are constantly involved in the grinding processes influence the properties (mechanical and chemical) of abrasive grains; it may result in a reduction of wheel service life (Wang et al, 2015).

In addition, the excessive quantity of energy generated in the grinding process can cause tool distortion, and it adversely affects the dimensional accuracy of the workpiece and, consequently, the quality of the finishing operation is limited (Guo et al., 2005) Thereby, cutting fluids are applied in order to minimize the deleterious effects caused by excessive heat in the cutting zone (Irani et al., 2007). Coolants play important roles in grinding, as they

\section{Experimental procedure}

The experimental trials were carried out on a CNC cylindrical plunge grinding machine (RUAP 515H model). Specimens were manufactured in ring-shaped workpieces of AISI 4340 steel, quenched and tem- can ensure cooling the workpiece and lubrication of the contact zone between workpiece and grinding wheel, as well as removing and cleaning chips in the cutting zone; as such, the service life of wheel grinding is prolonged and the quality of workpiece is improved.

Despite the fact that technological advantages are evident with the usage of cutting fluids, some negative effects have been discussed in recent years (Dhar et al., 2006). According to Brinksmeier et al. (2010), high peripheral velocity and the fact that fluids are pressurized into the cutting zone under high pressure can produce the occurrence of dangerous aerosols that are hurtful to human skin and can be inhaled. Moreover, not only is the disposal of cutting fluid waste complex, but so is their storage. The total cost with cutting fluids (including storing, filtering and disposal waste) in some cases is more expensive than tooling costs (Sanchez et al., 2010).

Aiming to substantially reduce the consumption of cutting fluids and their risks to human health, as well as to decrease environmental impacts caused by the conventional machining process, the Minimum Quantity Lubrication (MQL) technique was developed. In fact, the Minimum Quantity Lubrication (MQL) technique is an alternative to conventional application of cutting fluids. The method basically consists of lubricating oil with compressed air flow resulting in a mixture which is delivered directly into the grinding region. The application of this cooling-lubricating method avoids the use of cutting fluid by flooding the machining zone, reducing substantially the volume of cutting fluid used (Obikawa et al., 2006). By this way, it is mandatory that the minimum quantity of lubricant promote a decrease of friction, avoiding material adherence. Since this technique involves a low quantity of lubricant and compressed air flow, a mist of oil and air is created in the wheel-workpiece inter- face. When the lubricating technique does not suitably remove the heat generated from the cutting zone, risks to tool and workpiece integrity are increased due to high temperatures in the cutting area which are related to a grinding process with use of conventional wheel grinding (Oliveira et al., 2012).

Moreover, numerous works and experiments indicate the MQL coolant technique cannot only improve the grinding properties under particular experimental conditions, but also can ensure better lubrication than the conventional coolant delivery technique. The most important fact about this technique is the substantial reduction of the coolant volume or flow rate employed $(600,000 \mathrm{ml} / \mathrm{h}$ to $240 \mathrm{ml} / \mathrm{h}$, which represented a drop of $99.96 \%$ ), whereby hazards to employee and environment are reduced (Zhang et al., 2015).

In order to explore the potentialities of the MQL technique for a cleaner machining, lower costs and decrease of risks to human health and environment, this work aims to evaluate the application viability of the minimum quantity lubrication coolant technique in the plunge cylindrical grinding of ABNT 4340 steel with an aluminum oxide wheel under different coolinglubrication conditions. In this way, the main purpose of this work is not only to substantially reduce the volume of oil employed by conventional technique in grinding process, but also the propose consists of reducing the volume of oil employed by the ordinary MQL technique $(240 \mathrm{ml} / \mathrm{h})$. The MQL technique tested involved three different flow rates which were proposed (30, 60 and $120 \mathrm{ml} / \mathrm{h}$ ) and were compared with the conventional application of cutting fluid. All the coolant techniques were evaluated by measuring the following output parameters: roughness, roundness, micro-hardness of the workpiece, grinding wheel wear and power consumption. pered $(697 \mathrm{HV})$, with dimensions of $54 \mathrm{~mm}$ $\pm 0.1 \mathrm{~mm}$ outer diameter, $30 \pm 0.1 \mathrm{~mm}$ internal diameter, and $4 \pm 0.1 \mathrm{~mm}$ thickness. A white aluminum oxide abrasive wheel with 355.6 $\mathrm{mm}$ outer diameter, $127 \mathrm{~mm}$ internal di- ameter, $25.6 \mathrm{~mm}$ width, and vitrified bond was used in the grinding tests. The grinding wheel was produced by NORTON Co. A summary of the machining conditions employed in this work is presented in Table 1. 


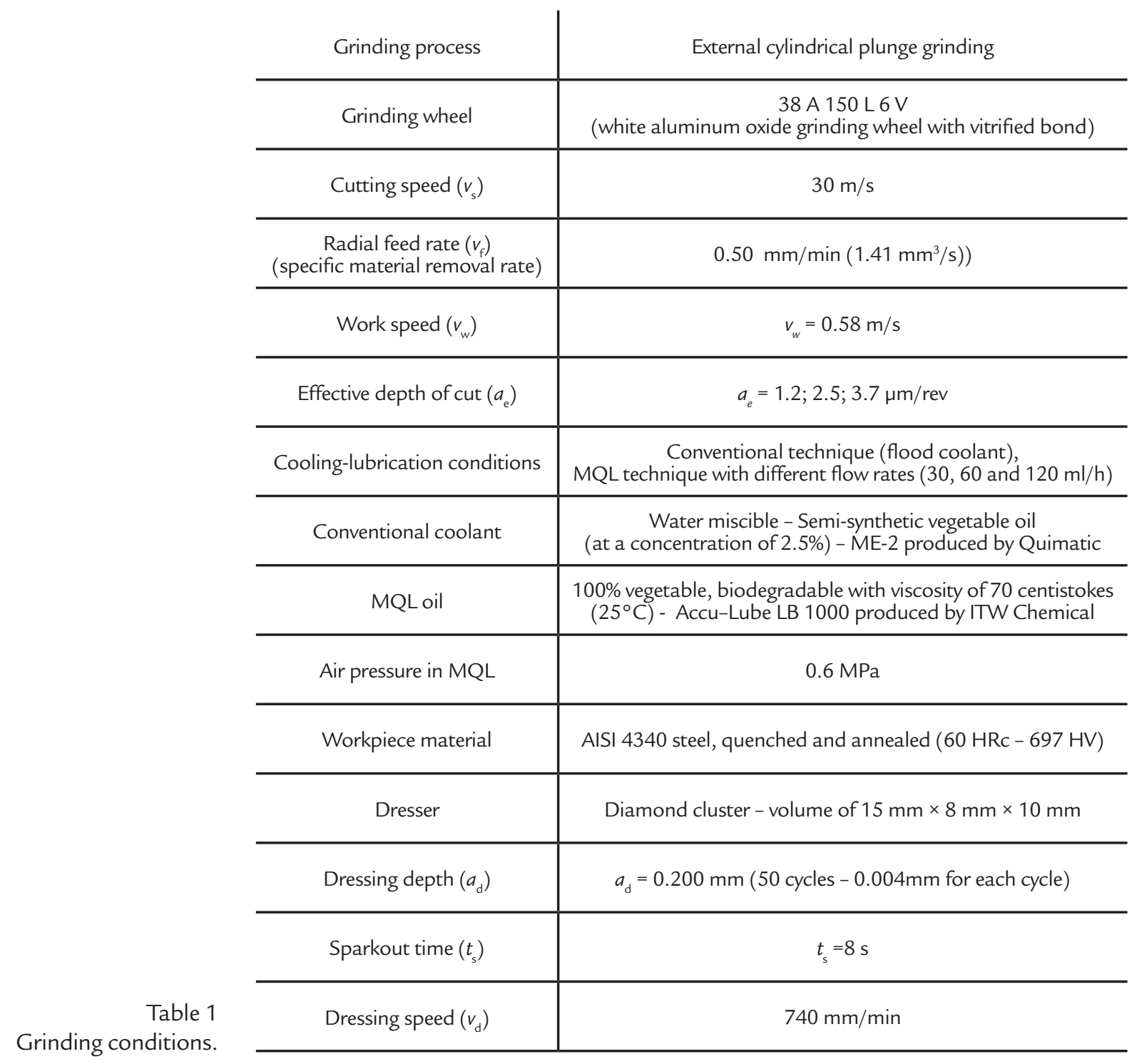

The MQL system used was integrated with the following components: air compressor, pressure controller, flow measuring device and mixer nozzle. The pulsating system was comprised of a builtin intermittent oil supply, which allowed the separately controlled the flow rate of compressed air and lubricant fluid.

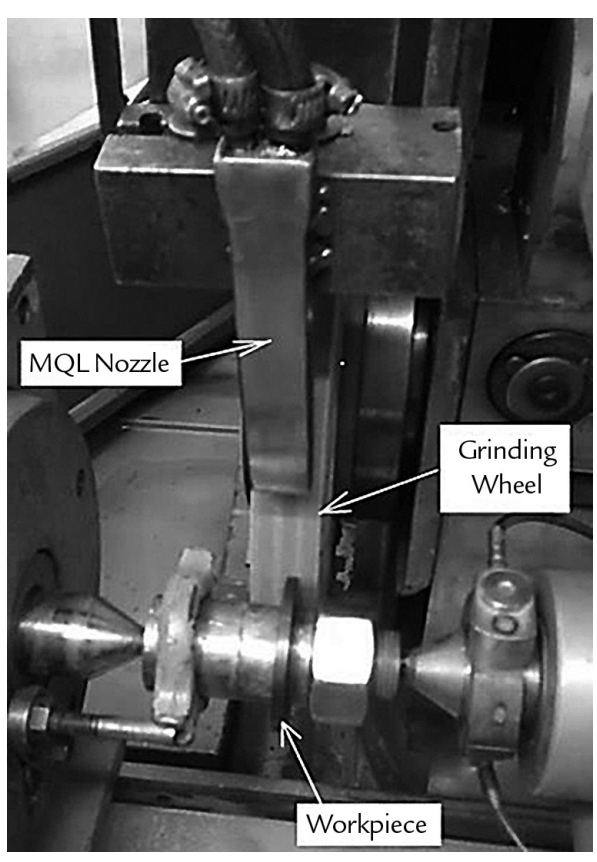

A turbine flow meter was used in order to monitor the compressed air flow rate. Figure 1 shows the physical picture of the experimental setup.
Figure 1

Experimental setup. 
The surface roughness Ra parameter was measured using Taylor Hobson Surtronic3+ portable stylus instrument. The measurements were taken using a cut-off of $0.25 \mathrm{~mm}$ and $1.25 \mathrm{~mm}$ sampling length. The measurement results correspond to the average of readings in three different positions $\left(120^{\circ}\right.$ spacing) for each workpiece under the same cooling-lubrication condition. Similar to the methodology for measuring roughness, roundness error measurements were obtained in all experiments with the aid of a Taylor Hobson Talyrond 31C device. This equipment has a mobile arm supplied by a ruby ball which touches the workpiece in order to obtain the roundness error value.

The measurements of the workpiece were taken in a micro-hardness tester from Mitutoyo, HM-211 model. A load of $300 \mathrm{~g}$ during $40 \mathrm{~s}$ was used for a better view of indentation. With the purpose of examining the occurrence of possible alteration in the microstructure, the specimens which presented the lowest standard deviation for roughness and roundness were assessed by optical microscopy (Olympus BX-51) with 500x magnification.

In terms of wheel wear measurements, a cylindrical AISI 1020 steel workpiece was used for printing the wheel profile. This technique is widely employed because the profile produced in the wheel surface during the grinding experiment can be printed on the soft steel cylinder. The diametrical wheel wear was measured via profile projection and measurement with the aid of surface roughness meter software (Taylor Hobson TalyMap).

Grinding power was monitored through energy consumed in the grinding machine axis by a sensor placed on the machine, which transmitted signals to an A/D board, and then data were read in a computer, using the National Instruments LabVIEW.

\section{Results and discussion}

In this session, results and discussion are presented for the output variables previously mentioned.

\subsection{Surface roughness}

Figure 2 compares the mean values of the Ra parameter $(\mu \mathrm{m})$ obtained after grinding under 4 different cooling-lubrication techniques. It can be seen from this figure that roughness values are lower in the conventional coolant application when compared with the results obtained after machining under application of the MQL technique. It is in contrast to results that have been presented by Silva et al. (2013), whose tests employed the same workpiece material in similar grinding conditions, with exception of the abrasive wheel (they have employed a vitrified CBN grinding wheel). The results obtained by the authors showed a better MQL performance in terms of superficial roughness due to a bet- ter lubrication property of the oil delivered into the wheel-workpiece interface.

Superficial finishing significantly affects the fatigue resistance of machined components; in special these are subjected to work conditions with alternating stresses and high temperatures (Malkin and Guo, 2008). Thereby workpiece roughness has a direct connection with lubrication, depending on the shape of the abrasive grain, as well as the dressing conditions, feed rates, sparking time and cooling-lubrication conditions. Furthermore, in the machining process, if lubrication and cooling aren't satisfactory, excessive temperatures can cause thermal damage to the workpiece, as well as burns, microstructural alteration, residual tension, geometric errors and quality deterioration of final workpiece produced. In the case presented herein, it can be inferred that plunge cylindrical grinding of the ABNT 4340 steel grade via the Minimum Quantity Lubrication (MQL) coolant technique represented a less satisfactory condition when related to the conventional coolant method, but results obtained in $120 \mathrm{ml} / \mathrm{h} \mathrm{MQL} \mathrm{ap}$ plication were close to the conventional one. Moreover, all the roughness results were lower than $1.4 \mu \mathrm{m}$, below the stipulated rejection limit of $1.6 \mu \mathrm{m}$ for the grinding operation commonly reported in literature.

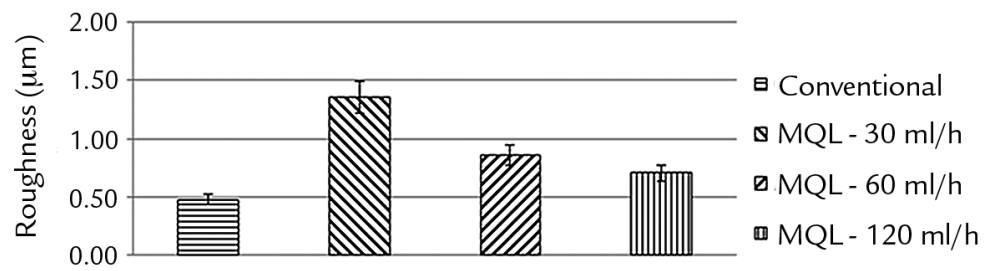

It can be seen from Figure 2 that among the flow rates of coolant delivered by the MQL technique, the flow rate $120 \mathrm{ml} / \mathrm{h}$ outperformed the other ones in term of roughness results. Malkin and Guo (2008) reported the highest values for $\mathrm{Ra}$ parameter after performing the grinding operation with a flow rate of $30 \mathrm{ml} / \mathrm{h}$. They attributed this to a non-satisfactory cooling-lubrication function in cutting with this flow rate. By the fact that MQL with $120 \mathrm{ml} / \mathrm{h}$ flow rate presented lower roughness results in relation to those obtained for $60 \mathrm{ml} / \mathrm{h}$ and $30 \mathrm{ml} / \mathrm{h}$ flow, it can be inferred that a combination between the considered flow and aluminum oxide grinding wheel helped in promoting better evacuation of chips from the contact zone, thereby preventing the occurrence of wheel clogging (Marinescu
Figure 2

Surface roughness Ra parameter $(\mu \mathrm{m})$ obtained after grinding the ABNT 4340 steel under different cooling-lubrication techniques and flow rates.

et al., 2007). According to Oliveira et al. (2012), chips at high temperatures which are generated in the grinding process have a high tendency to lodge into the pores of the grinding wheel. By non-occurrence of the wheel clogging phenomenon in relation to $\mathrm{MQL}$ with $120 \mathrm{ml} / \mathrm{h}$ flow rate, this flow was related to the closest $\mathrm{Ra}$ parameter value in comparison to the conventional coolant technique. 


\subsection{Roundness}

Figure 3 presents the mean values of roundness errors (in $\mu \mathrm{m}$ ) after grinding

Figure 3

Roundness errors after

grinding ABNT 4340 steel under different cooling-lubrication techniques and flow rates.

As can been seen from Figure 3, the lowest roundness error was recorded after machining under the conventional coolant technique. Roundness error is directly related to grinding conditions, also thermal damages, mechanical loads, cutting fluid flow and pressure. Roundness error indicates variation of workpiece geometry. A machining process with high generation of heat can promote dimensional and geometrical variation on the workpiece (Hadad et al., 2012). Machining with the conventional coolant technique exhibits the highest refrigeration capability to remove heat from the cutting zone in comparison with the MQL technique, which employed the lowest amount of neat oil. Ding et

\subsection{Diametrical wheel wear and grinding power}

Figure 4 shows the diametrical abrasive wear values measured in the aluminum oxide grinding wheel after grinding the AISI 4340 steel for each tested coolinglubrication condition. It can be seen that wheel wear values were lower after machining under the conventional coolant

Figure 4

Diametrical wheel wear after machining after grinding ABNT 4340 steel under different cooling-lubrication techniques and flow rates.

According to Silva et al. (2007), diametrical wheel wear is lower since coolinglubrication is increased by the cutting fluid action. In fact, the decrease of friction among abrasive grains, workpiece and chips permits abrasive grains to stay longer attached to the bond, minimizing wheel wear. Besides, diametrical wheel wear is related to the following two causes: thermal

test under each cooling-lubrication condition which was employed.

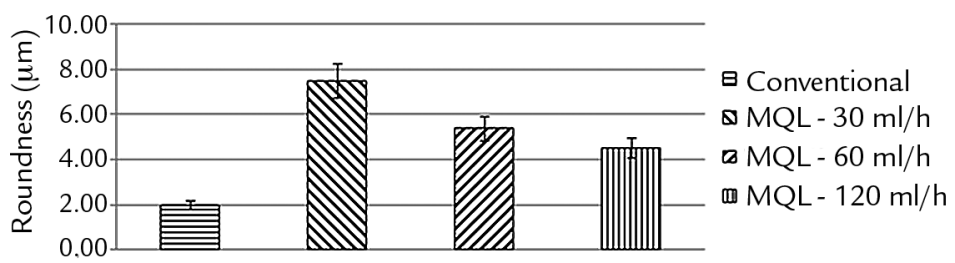

al. (2014) also found reported that the conventional cooling-lubrication method was more efficient than the MQL technique in cleaning the wheel. Similarly, as for surface roughness, the higher the volume of cutting fluid applied, the more effective was the wheel cleaning, reducing roughness and roundness errors. The behavior of the roundness error curve is similar to that for surface roughness (Fig. 1). With regard to the MQL technique, in special, the lowest roundness errors were recorded after machining with the highest flow rate of $120 \mathrm{ml} / \mathrm{h}$ flow, being followed by $60 \mathrm{ml} / \mathrm{h}$ and 30 $\mathrm{ml} / \mathrm{h}$. During the grinding process, lower dissipation of heat occurs in the cutting zone due to the reduction of the amount of cutting fluid, and consequently, thermal expansion of workpiece results in higher roundness errors (Fusse et al., 2004). Therefore, based on the results obtained for roundness errors, it can be concluded that machining with the MQL with flow rate of $120 \mathrm{ml} / \mathrm{h}$ outperformed the other flow rates.

Furthermore, machining with MQL and flow rate of $120 \mathrm{ml} / \mathrm{h}$ provided superior tribological properties in cylindrical grinding of the ABNT 4340 steel under the conditions employed in this work. Therefore, the chip removal capacity was more efficient than that observed by the two other flow rates of fluid $(30 \mathrm{ml} / \mathrm{h}$ and $60 \mathrm{ml} / \mathrm{h}$ ) delivered by MQL, which were impaired by wheel clogging. delivery method. Again, this condition outperformed the MQL technique, irrespective of the flow rate employed, similar to results obtained in terms of roughness and roundness (as shown in Figures 2 and 3, respectively). When the MQL technique was employed, it was observed that the higher the flow rate, the lower was the diametrical wheel wear. This trend allows inferring the coherence among results for wheel wear, roundness and roughness, since the highest roughness values correspond to the machining condition that presented the highest diametrical wheel wear. deterioration and high mechanical loads to which the grinding wheel is subjected. According to Walker (2013), optimization of the MQL technique is recommended for jobs that are repeated or that are run for a long time, like in the grinding operation, for instance. This author also states that one of the advantages of this method is flushing of swarf away from the grinding zone, thereby avoiding gumming.

From Figure 5, it can be observed that behavior is very similar to that recorded for diametrical wheel wear, roughness and roundness. Furthermore, the more the flow rate of the fluid increased, the less the grinding power consumed. This can be attributed to the superior cooling capacity of the conventional coolant method 
to remove heat from the wheel-workpiece system. When the lubrication which is gen- erated by the cooling-lubrication technique is reduced, cutting forces between wheel and workpiece increase, and more power is required to perform cutting.

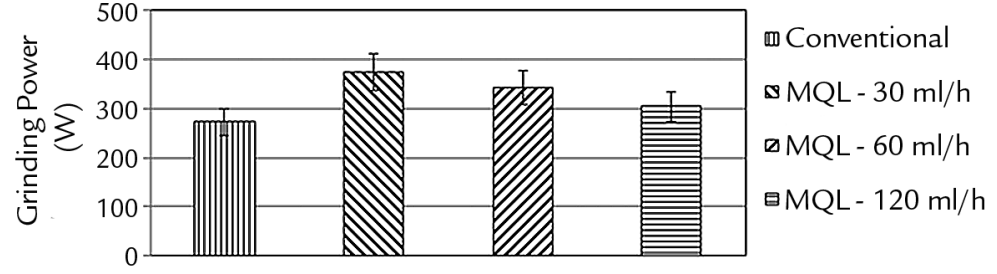

Barczak et al. (2010) carried out a study in plane surface grinding with different coolant-lubrication techniques (conventional (wet) and MQL) of several steels grades with alumina wheel and reported that the MQL technique outperformed the conventional method in terms of cutting forces and grinding power. The

\subsection{Optical microscopy and micro-hardness}

Aiming to detect possible alteration of workpiece microstructure after a grinding process under different conditions of

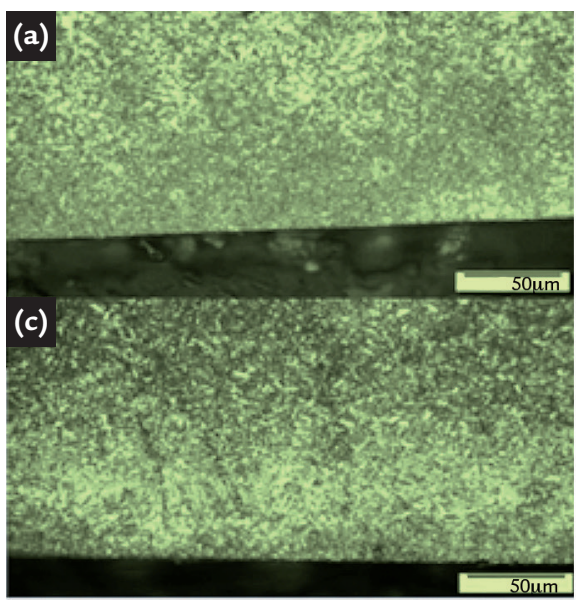

As can be observed in Figure 6, no surface burns or tempering occurred on the surfaces and sub-surfaces of the ground materials, irrespective of the coolantlubrication technique employed. According to Klocke et al. (2005), non-occurrence of microstructural alteration is a crucial requirement for industries, since the following parameters are guaranteed such
MQL technique yielded the lowest forces, about $42 \%$ lower than for conventional method. They attributed this fact to the results of hydrodynamic effects increasing power consumption when machining under the conventional coolant method and the improved lubrication properties of the MQL oil.

cooling-lubrication techniques, the optical microstructure and micro-hardness analysis was carried out for one specimen from

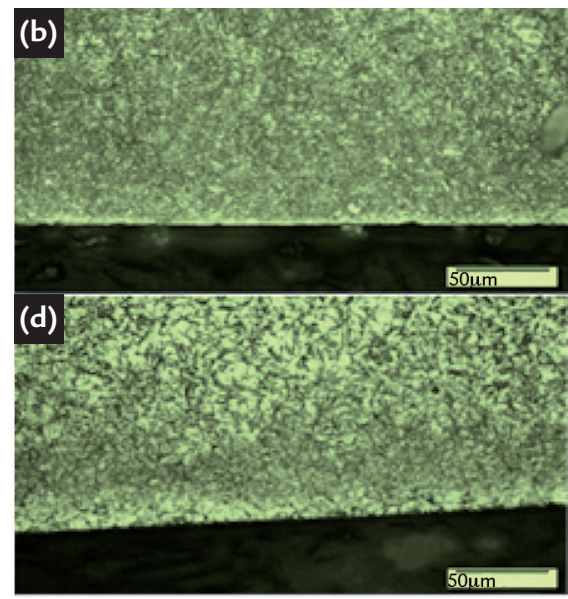

as: microstructural quality, mechanical properties of project and machining efficiency. Furthermore, this practice allows avoiding economic loss because of the fact that grinding is the final process in the productive cycle.

Figure 7 shows the Vickers microhardness results recorded as a function of each cooling-lubrication condition

Figure 5

Grinding power consumed during grinding ABNT 4340 steel under different cooling-lubrication techniques and flow rates.

The results which were obtained for grinding power were associated with the ones related to diametrical wheel wear, and ratifies the fact that the higher recordings for grinding power are inherent to the tests which presented the higher values for diametrical wheel wear, since they involved higher mechanical stresses.

each condition tested. The microstructure obtained for each condition tested is shown in Figure 6.

Figure 6

Micrographs of workpieces after grinding under: a) conventional coolant technique; b) MQL technique with $30 \mathrm{ml} / \mathrm{h}$; c) MQL technique with $60 \mathrm{ml} / \mathrm{h}$ and d) MQL technique with $120 \mathrm{ml} / \mathrm{h}$.

employed. Considering that the reference value for micro-hardness measured prior to grinding trials is near $697 \mathrm{HV}$, it can be seen from Figure 7 that workpieces experienced a slight drop in hardness up to 60 $\mu \mathrm{m}$ at a depth below machined surface for all the conditions investigated in this work. The highest drop in hardness was observed after machining with the MQL technique

Figure 7

Micro-hardness below the ground surface after grinding ABNT 4340 steel under different cooling-lubrication techniques and flow rates. 
using $30 \mathrm{ml} / \mathrm{h}$. Since thermal damage can be characterized as microstructural alterations, when altering the mechanical

\section{Conclusions}

The following conclusions can be drawn from this research:

- Considering the quality parameters of roughness and roundness, the MQL technique showed performance to be inferior to the conventional coolant method. However, among the flow rates tested for the MQL technique, 120 $\mathrm{ml} / \mathrm{h}$ flow rate outperformed the other flow rates due to the improved coolantlubrication properties. Results from this condition were close to those recorded by the conventional coolant method;

\section{Acknowledgments}

Special thanks to FAPESP (State of São Paulo Research Assistance Foundation - Process Number 2015/091977), FAPEMIG and CNPq (National

\section{References}

properties of ground material by the results in Figures 6 and 7, it can be inferred that there was no significant alteration in work-

- Machining under the MQL technique also exhibited inferior performance in comparison to the conventional coolant method in terms of wheel wear and power consumed;

- Although no surface burns or tempering occurred on the surfaces and sub-surfaces of the ground materials, irrespective of the coolant-lubrication technique employed, there was observed a slight drop in hardness up to $60 \mu \mathrm{m}$ at a depth below the machined surface after machining with the MQL technique

Counsel of Technological and Scientific Development) for supporting this work. One of the authors thanks to CAPES for the financial support given by a piece microstructure due to grinding temperatures.in all of the cooling-lubrication conditions tested in this work.

with $30 \mathrm{ml} / \mathrm{h}$;

- MQL with $120 \mathrm{ml} / \mathrm{h}$ was a technically viable coolant means in grinding of the ABNT 4340 steel with an aluminum oxide wheel due to the cleaner environment and lower consumption of fluid compared to the conventional coolant method. Therefore, this condition generated the closest results to the conventional application of cutting fluid, showing it to be a competitive technique when the decrease of risks and costs are considered.

PNDP project - post doctoral scholarship at the FEB-UNESP-BAURU.

BARCZAK, L.M., BATAKO, A.D.L., MORGAN M.N. A study of plane surface grinding under minimum quantity lubrication (MQL) conditions. International Journal of Machine Tools \& Manufacture, v. 50, p. 977-985, 2010.

BRINKSMEIER, E., MUTLUGÜNES, Y., KLOCKE, F., AURICH, J.C., SHORE, P., OHMORI, H. Ultra-precision grinding. CIRP Annals - Manufacturing Technology. v. 59, p. 652-671, 2010.

DHAR, N., ISLAM, S.; KAMRUZZAMAN, M. Effect of minimum quantity lubrication (MQL) on tool wear, surface roughness in turning AISI-4340 steel.Journal of Materials Processing Technology, 172, p. 299-304, 2006.

DING, K., FU, Y., SU, H., GONG, X., WU, KEQIN. Wear of diamond grinding wheel in ultrasonic vibration-assisted grinding of silicon carbide. International Journal of Manufacturing, 2014.

FUSSE, R.Y., FRANCA, T.V., CATAI, R.E., SILVA, L.R., AGUIAR, P.R.;BIANCHI, E.C. Analysis of the cutting fluid influence on the deep grinding process with a CBN grinding wheel. Sao Carlos, SP, Materials Research, - v. 7, n. 3, p. 451-457, 2004.

GUO, C., SHI, Z., ATTIA, H., MCINTOSH, D. Power and wheel wear for grinding nickel alloy with plated CBN wheels. CIRP Annals - Manufacturing Technology, v. 56, p.343-346, 2007.

HADAD, M.J., TAWAKOLI, T., SADEGHI, M.H., SADEGHI, B. Temperature and energy partition in minimum quantity lubrication - MQL grinding process. International Journal of Machine Tools \& Manufacture, p. 54-55, 10-17, 2012.

IRANI, R. A., BAUER, R. J., WARKENTIN, A. A review of cutting fluid application in the grinding process. Int. J. Machine Tools \& Manufacture, 45, p.1696$1705,2005$.

KLOCKE, F., BRINKSMEIER, E., WEINERT, K. Capability profile of hard cutting and grinding process. CIRP Annals - Manufacturing Technology. v. 54, Issue 2, p. 22-45, 2005.

MALKIN, S., GUO. C. Grinding technology: theory and applications of machining with abrasives. New York: Industrial Press, 2008.

MARINESCU, I.D., HITCHINER, M., UHLMANN, E., ROWE, W.B, INASAKI, I. Handbook of Machining with Grinding Wheels. USA: CRC Press, Taylor \& 
Francis Group, 2007.

MARINESCU, I. D., ROWE, W.B., DIMITROV, B., INASAKI, I. Tribology of abrasive machining processes. (2nd ed.) Norwich: William Andrew Inc, 2013.

NGUYEN, T.A., BUTLER, D.L. Simulation of precision grinding process, part 1: generation of the grinding wheel surface. International Journal of Machine Tools \& Manufacture, v.45, p. 1321-1328, 2005.

OBIKAWA, T., KAMATA, Y., SHINOZUKA, J. High-speed grooving with applying MQL. International Journal of Machine Tools \& Manufacture, 46, p.1854-1861, 2006.

OLIVEIRA, D.J., GUERMANDI, L.G., BIANCHI, E.C., DINIZ, A.E., AGUIAR, P.R., CANARIM, R.C. Improving minimum quantity lubrication in CBN grinding using compressed air wheel cleaning. Journal of Materials Processing Technology. v.212, p.2559-2568, 2012.

WANG, Y.G., LI, C.H., LI, B.K., YANG, M., ZHANG, X.W. Advances and recent patents in the field of grinding temperature measurement methods. Bentham Science. 2015.

SANCHEZ, J.A., POMBO, I., ALBERDI, R., IZQUIERDO, B., ORTEGA, N., PLAZA, S. MARTINEZTOLEDANO, J. Machining evaluation of a hybrid MQLCO2 grinding technology. Journal of Cleaner Production, 18, p. 1840 - 1849, 2010.

SILVA, L.R., BIANCHI, E.C., FUSSE, R.Y., CATAI, R.E., FRANCA, T.V.; AGUIAR, P.R. Analysis of surface integrity for minimum quantity lubricant-MQL in grinding. International Journal of Machine Tools \& Manufacture, v. 47, p. 412-418, 2007.

SILVA, L.R., CORRÊA, E.C.S., BRANDÃO, J.R., DE ÁVILA, R.F. Environmentally friendly manufacturing: behavior analysis of minimum quantity of lubricant - MQL in grinding process. Journal of Cleaner Production, 2013.

WALKER, T. The MQL Handbook - a Guide to machining with minimum quantity lubrication. Unist, Inc. v. 1.0.3, 2013. 43 p.

ZHANG, Y.B., LI, C.H., JIA, D., ZHANG, D.K., ZHANG, X.W. Experimental evaluation of MoS2 nanoparticles in jet MQL grinding with different types of vegetable oil as base oil. Journal of Cleaner Production, v. 87, p. 930-940 15 January 2015.

Received: 3 January 2017 - Accepted: 27 June 2017. 